\title{
Russian Political Theology in an Age of Revolution
}

Randall A. Poole

I

One of the most important directions in religion today is political theology. ${ }^{1}$ It is not a new concept, but it has taken on a new meaning within the past fifty years, so much so that scholars now distinguish between the old and the new political theology. ${ }^{2}$ The old goes back to the ancient empires of the Near East, and refers to the use of religion to sanction or legitimate a given political order. Augustine of Hippo, in the City of God, criticized the old Roman political theologies and opposed the sacralization of any earthly political order, but his pessimistic conception of human nature, with its emphasis on human depravity and original sin, formed the basis for its own type of old political theology: for him, salvation largely meant salvation from ourselves, by the external action of grace and the church acting as its earthly instrument. Accordingly, Augustine condoned the use of state power against heretics who challenged church dogma and threatened salvation. In general, the old political theology was premised on an external approach to salvation, with external (i.e., political) power being seen as a necessary means to salvation-the salvation of those subject to such power. After Augustine, political theology fell into long disuse as a theoretical concept, though certainly not as a political practice. It was reintroduced into modern discourse by Carl Schmitt in his 1922 essay Politische Theologie (Political Theology). (Schmitt later served as "crown jurist" of the Third Reich.) Despite some new theoretical content, Schmitt basically perpetuated the old meaning of the term, that is, the subordination or instrumentalization of religion for political purposes, which purposes were, for Schmitt, the only absolute ones. 
The new form of political theology was founded in the 1960s and 1970s by a very different German thinker, the Catholic theologian Johann Baptist Metz. It refers not to the ideological legitimization of political power but to the theological analysis, criticism, and justification of politics, society, and history. In Metz's conception, political theology is a "practical fundamental theology" that seeks to ground politics in a theological anthropology and to elaborate a theological or normative framework for political and social praxis. ${ }^{3}$ The old political theology was more about politics than theology, and tended to reduce theology to political purposes. The new political theology, by contrast, is first and foremost about theology. It conceives politics in relation to the absolute values and ends of theology, which means re-conceiving politics as the ways human beings work and struggle together in history and society to realize ever more fully their personhood (or, as Metz often puts it, "to become subjects before God"4), to build a just society befitting them as persons or subjects, and to take responsibility-as autonomous, selfdetermining moral subjects or agents-for their salvation. The very idea of God, according to Metz, is an "ineluctably political one," because it expresses an option: "opting for a state of affairs in which all people are able to be subjects and ought to become subjects" (76). In this way Metz directly relates the idea of God to the human capacity for selfdetermination, self-realization, and subjecthood. Here is the profound humanism of the new political theology, in stark contrast to the old.

\section{II}

In 1999 Rowan Williams published a fine edition of the writings of twentieth-century Russia's most important theologian, Sergei Bulgakov. ${ }^{5}$ Williams chose as the subtitle for his book, "Towards a Russian Political Theology," clearly referring to the new political theology. ${ }^{6} \mathrm{He}$ writes that Bulgakov's thought "could well be read as a systematic attempt to work out the basis on which political action and policy could be seen as philosophically_and, eventually, theologically-legitimate" (7). In this article I shall argue, following Williams's lead, that the Russian religiousphilosophical tradition, as represented by Bulgakov and other members 
of the Vekhi group, is both a remarkable anticipation of the new political theology and a trenchant critique of the old.

The Williams collection includes one of Bulgakov's lesser-known texts, "Dusha sotsializma" ("The Soul of Socialism," 1932-33). This essay offers perhaps the best succinct justification of Williams's subtitle. Bulgakov's main themes here are human personhood, human work, and human history. Socialism, in his account, misunderstands all of them. Its anthropology or conception of human nature is based on two doctrines, "sociologism" and "economism," which together make up the impoverished soul of socialism. Sociologism dissolves the individual human person in the social whole and denies its independent reality, freedom, and creativity. Economism debases human work and economic activity. In Marxism it is materialistic and even "zoological" (240). Bulgakov commends instead the sophiological approach to economy that he developed in his 1912 treatise Filosofiia khoziaistva (Philosophy of Economy), ${ }^{7}$ which understands that through free, creative work man humanizes the world and transforms it in his own image. This sophianic work takes place in history, and with this Bulgakov turns to his conception of human history, his most important theme. He advances an activist, humanist understanding of eschatology, one that is strikingly similar to Metz's new political theology some forty years later.

Bulgakov's main burden is to reconcile eschatology, the transcendent fulfillment and end of history, with human responsibility for it within history. History and eschatology have, according to him, been too long separated and set in opposition to each other, the link between them denied. $\mathrm{He}$ calls this separation "eschatological transcendentalism," whereby "all earthly illumination is quenched and all earthly values destroyed: all that remains is personal merit and personal sin, with their equivalents of reward or punishment, which each individual receives for himself alone, without any regard to the collective work of humanity in history" (244). Such eschatological transcendentalism leads to historical nihilism: in order for history to have meaning and value, people must believe that they are responsible for it and are working toward its culmination. In this sense, "history has its own inner apocalypse, which makes history itself already eschatology fulfilling itself in time"-though the fulfillment remains 
ultimately transcendent (244). Thus Bulgakov tries to preserve the idea of a transcendent eschaton with an immanent goal of human aspiration.

He links his philosophy of history with a critical "sense of an orientation towards the future, with consciousness of obligatory tasks to be performed and of continuing historical labour" (253). This "orientation towards the future" is a type of utopianism, in the positive sense of the human capacity to imagine the future and to work toward it as an ideal. Bulgakov describes utopia-"an object of social faith, hope and love"-in terms of the biblical definition of faith, "the assurance of things hoped for, the conviction of things not seen" (Heb. 11:1). Utopia, he writes, is "an ideal with a changing content," depending on the specific historical circumstances. ${ }^{8}$ In his conception, utopian ideals are the driving force behind historical progress; they take us ever beyond present historical reality and constantly into the future. But such ideals must remain rooted in religious consciousness; otherwise they collapse into the "tired positivism" that is inimical to the very concept of the ideal (248-49).

The supreme ideal is the Kingdom of God. It cannot remain a "purely passively understood prophecy" but must become "an active utopian ideal, a hope"-in short, a human task. "Naturally this symbol in itself is abstract," Bulgakov writes, "but it is constantly being filled out with concrete content, in terms of actual advances or achievements in history, of the summons directed by the future towards the present" (257-58). He contrasts this activist and progressive philosophy of history to "pseudo-eschatologism," which resigns before the eschaton and shuns historical responsibility. $\mathrm{He}$ extols the Hebrew (Old Testament) prophetic tradition, with its sweeping utopian vision ("in the positive sense of 'utopian, of course") and demand for social justice. The New Testament brought a definite shift, as expectations of the imminent end of the world brought about a certain indifference to history, social quietism, and "a peculiar kind of apolitical vision" (254). From this come Bulgakov's efforts to historicize the Apocalypse. He calls hopefully for a Christian reformism, inspired by the active utopian ideal of the Kingdom of God.

"The Soul of Socialism" is a landmark essay. In Williams's estimation, it "draws together a remarkable range of Bulgakov's ideas, and displays some of the deepest continuities in his thought" (235). A year later, in his "Social 
Teaching in Modern Russian Orthodox Theology," which was delivered as a lecture at the Seabury-Western Theological Seminary in Evanston, Illinois, Bulgakov used a simple but apt term to describe the main direction of his theology and of modern Russian theology as a whole: "Christian humanism." Its distinctiveness, again simply and aptly put, is that "it includes the creativity of man in the means of his salvation" (283). This type of religious humanism, with its faith in the efficacy of human work and progress toward salvation, is also the distinctive feature of the new political theology and of its antecedents and correlates, such as nineteenth-century Kantian liberal theology, the social gospel movement, and liberation theology.

\section{III}

"The Soul of Socialism" was published in German translation in 1977,9 the same year that Johann Baptist Metz's most important work, Glaube in Geschichte und Gesellschaft (Faith in History and Society: Toward a Practical Fundamental Theology), appeared. ${ }^{10}$ Metz describes his theology as "the struggle for the subject-or, practical fundamental theology as the political theology of the subject" (70). This is a meaningful formulation. First, the term "practical" signals not only Kant's moral philosophy but also the humanist dimension of Marxism, both of which have decisively shaped Metz's thought. ${ }^{11}$ Second, Metz's term "subject" indicates his focus on human personhood. He prefers "subject" to emphasize human autonomy, agency, and responsibility, but those qualities can, of course, be emphasized in the term "person" as well, as they were by Bulgakov and other Russian neo-idealist philosophers. Metz has had an abiding preoccupation with theological anthropology; his first major work was Christliche Anthropozentrik (Christian Anthropocentrism, 1962). ${ }^{12}$

The thesis of Faith in History and Society is that people are called to become subjects in the presence of, and through their relationship to, God. This idea has a dual meaning: first, God wants us to be subjects; second, God wants us to be subjects even in his presence, that is, he wants us to preserve our autonomy and responsibility in his presence rather than to be overwhelmed by it. As Metz writes, "the relationship to God does not 
become the expression of a slavish subjection and enervated devotion; it does not humiliate persons as subjects" (71). ${ }^{13}$ Human beings can become subjects before God only in history and society. This is necessarily a struggle-Metz refers to the "historical struggle for humanity"-and human beings are subjects most when they struggle to help others become subjects. The implication, Metz stresses, is that people struggle to become subjects in solidarity with each other. The historical struggles for all human beings to be subjects, and by which they become subjects, is the main theme of Metz's political theology.

This theme is an eschatological one. In his 1968 book Zur Theologie der Welt (Theology of the World), ${ }^{14}$ Metz wrote, "The universal existentialanthropological viewpoint in Christian theology depends on the eschatological viewpoint. This is true, because only in the eschatological horizon of hope does the world appear as a reality coming into being, whose development and process is handed over to the free action of man." ${ }^{15}$ The "eschatological horizon of hope" is a telling expression. It makes clear the humanism of Metz's understanding of eschatology. For him, as for Bulgakov earlier, eschatology stands for human freedom in history. History is the sphere of human freedom, because unlike the natural world, its future is open and undetermined. In his conception of history, especially the notion that history is the coming into being of that which has not yet existed, the Noch-nicht-gewesene, Metz drew on the Marxist thinker Ernst Bloch, who for a Marxist was uncharacteristically interested in religion. In the words of one Metz scholar, "the uniquely human capacity, which is the ground of genuinely free activity, is the capacity to envision this Noch-nicht-gewesene and orient one's activity by it. For Bloch this is the sensorium for Utopia. The power of utopia is what pulls history forward." ${ }^{16}$ Metz himself, in a famous passage, writes of utopia: "The name 'God' stands for the fact that the utopia of all human beings being liberated to become subjects possessed of human dignity is not a pure projection-which is certainly what it would be if there were only utopia and no God" (76).

The "struggle for the subject" is a theme that, given human nature and history, is full of suffering. Suffering in history, the theodicy problem, redemptive eschatology, and the meaning of progress in light of past suffering are all among the main concerns of Metz's new political theology. 
They are perennial Russian themes. Metz prefers to call them by the name "Auschwitz,"17 but Dostoevskii's treatment of them also helped to shape his thought. They are powerfully dealt with in Bulgakov's 1902 essay “Osnovnye problemy teorii progressa" ("Basic Problems of the Theory of Progress"). ${ }^{18}$ Earlier that year Bulgakov published his famous Dostoevskii essay "Ivan Karamazov kak filosofskii tip" ("Ivan Karamazov as a Philosophical Type"). ${ }^{19}$ Both Bulgakov and Metz level the same critique against the secular idea of progress, namely that it makes the suffering of past generations the "manure" (in Dostoevsky's expression) for the harmony of future ones. ${ }^{20}$ Contrary to its secular conception, they believe that progress needs to be reconceived as eschatology. ${ }^{21}$

Metz insists on separating his new political theology from the old, Carl Schmitt's in particular, for good reason. In the preface to Faith in History and Society, he writes that unlike "the classical 'political theology, ... the new political theology was never guided by the intention of exalting a politics that was already in force or on the increase anyway, and of simply copying theologically the way it operates" (xi). Other scholars agree. According to the authors of a recent short history of the concept, "The current positive theological use of political theology has to be understood as a reinvention of the term."22

Schmitt's use of the term was political rather than properly theological. In 1933 Erik Peterson formulated an influential critique of Schmitt, the so-called "Peterson thesis": "Political theology," he wrote, "is not really an element of theology but rather of political thought," and is in truth a political theory of a "particularly heretical nature." ${ }^{23}$ Peterson thought it particularly heretical because the political was the only absolute for Schmitt. In 1934, in his preface to the second edition of Political Theology, Schmitt wrote that "the political is the total." ${ }^{24}$ In that banal sense, Schmitt's idea of politics is "theological" (or "metaphysical"). Banal but dangerous: Schmitt recognized no limits on state power and endorsed the idea of the "total state." For him, "the specific political distinction to which political actions and motives can be reduced is that between friend and enemy," as he put it in his 1927 essay 
Der Begriff des Politischen (The Concept of the Political). ${ }^{25}$ The sovereign makes the distinction on the basis of nothing but arbitrary, raw power. There is no higher framework of morality or natural law. ${ }^{26}$

The title chapter of Political Theology opens with the following wellknown lines: "All significant concepts of the modern theory of the state are secularized theological concepts" (36). After Schmitt, a number of remarkable central European thinkers developed this insight into the powerful concept of "political religions," another variant of political theology. Among these scholars were Schmitt's disillusioned protégé Waldemar Gurian as well as Karl Löwith and Eric Voegelin. ${ }^{27}$ They saw contemporary totalitarian ideologies as secular forms of millenarianism and eschatology, which purported to offer collective terrestrial salvation by external political means. The link between political religions and the old political theology was their common illiberal, pessimistic view of human nature with their corresponding emphasis on external salvation (whether by church or party-state); this is also what separates them from the basic humanism of the new political theology, with its "faith in history and society" - its faith that human beings can work toward, and must take responsibility for, their salvation. (In contrast to the new political theology, conservative political philosophers such as Voegelin, on the basis of their analysis of political religions, reemphasized the radical distinction between the transcendent divine realm and the immanent realm of human existence in history. Their theological and anthropological presuppositions were rather different than those of thinkers such as Bulgakov and Metz. Bulgakov would have criticized Voegelin for "eschatological transcendentalism.")

Here as well, with the idea of political religions, Bulgakov and other Russian idealist philosophers were prescient. Even before the Russian Revolution, they interpreted positivism and socialism as secular religions, whose promise of salvation was based on a claim to knowledge of the laws and teleology of history, unfolding independently of human will but leading inexorably to the promised age. ${ }^{28}$ As early as 1878 Vladimir Solov'ev 
wrote, in his Chteniia o bogochelovechestve (Lectures on Godmanhood), that socialism and positivism were substitutes for "rejected gods." ${ }^{29}$ Bulgakov, as we shall see further, developed this approach in a number of his writings, including his essays "Basic Problems of the Theory of Progress" (1902), "Karl Marks kak religioznyi tip" ("Karl Marx as a Religious Type," 1906), and "Geroizm i podvizhnichestvo (Iz razmyshlenii o religioznoi prirode russkoi intelligentsii)" ("Heroism and Asceticism [Reflections on the Religious Nature of the Russian Intelligentsia]," 1909). ${ }^{30}$ Pavel Novgorodtsev also took up the theme. His 1917 book Ob obshchestvennom ideale ( $\mathrm{On}$ the Social Ideal) includes a long, seminal analysis of Marxism as a pseudoreligion of coerced collective salvation in history. ${ }^{31}$

Perhaps the most influential Russian proponent of the "socialism as religion" theme was Nikolai Berdiaev. ${ }^{32} \mathrm{He}$ addressed it in several of his prerevolutionary writings and in his widely read book Istoki i smysl russkogo kommunizma (The Origin of Russian Communism, 1937), where he depicts the Soviet state as an "inverted theocracy" in which everything assumes the character of orthodoxy or heresy. "The Soviet communist realm," he wrote, "has in its spiritual structure a great likeness to the Muscovite Orthodox Tsardom" - that is, to the old political theology of tsarist Russia. ${ }^{33}$ In his account, both the tsarist and communist autocracies were premised on the denial of freedom of conscience, because for them salvation was not a matter of inner self-determination and individual striving but of collective, external determination. The political religions approach remains influential among historians of totalitarianism today. ${ }^{34}$

What made the Russian neo-idealists such early and perceptive critics of twentieth-century political religions, and of the old political theology more generally, was their essential humanism, their belief, as Bulgakov put it, in the idea that human creativity is included in the means of salvation. For them, salvation was not something purely external (again, whether through grace, church, or party-state); rather, it depended on human self-determination and human self-realization, both individually and collectively. This is how the founder of modern Russian theology, Vladimir Solov'ev, understood salvation: the self-realization of humanity's intrinsic divine potential, or of Godmanhood (bogochelovechestvo), ultimately culminating in deification (theosis). ${ }^{35}$ The type of humanism expounded by Solov'ev and his followers 
is what distinguishes the new political theology from the old, then and now. ${ }^{36}$ Solov'ev even coined the term "Christian politics" to champion the consistent application of Christian moral principles to all spheres of human life (public as well as private) in the project of building of the Kingdom of God on earth. ${ }^{37}$

\section{VI}

This is the tradition, broadly, of Vekhi and of its predecessor volume, Problemy idealizma (Problems of Idealism, 1902). These two landmarks of the Russian Silver Age can be read, first, as powerful implicit critiques of the old political theology of the Russian autocracy; second, as critiques of the political religions of the Russian intelligentsia; and third, as classic texts of the new Russian political theology. Problems of Idealism is probably the most significant text in the first and third respects, while Vekhi focuses more on the salvific ethos of the intelligentsia and its belief in revolution as salvation.

Problems of Idealism was conceived at the beginning of the Russian Liberation Movement as a defense of freedom of conscience and its importance in liberalism. ${ }^{38}$ The volume's architects, Petr Struve and Novgorodtsev, understood freedom of conscience in two interrelated senses. First, it meant the inalienable right of the individual to determine his or her religious beliefs, a right not recognized by the tsarist government until the October Manifesto of 1905. Second, they understood freedom of conscience in the even more fundamental, Kantian sense as inner autonomy or self-determination according to freely recognized absolute ideals, which capacity Kant held to be the essence of morality, human dignity, and personhood itself. In their understanding of the dual meaning of the concept, Struve and Novgorodtsev followed the two greatest philosophers of nineteenth-century Russia, Boris Chicherin and Solov'ev. ${ }^{39}$

In its Kantian, liberal defense of self-determination and freedom of conscience, Problems of Idealism was a powerful critique of the old political theology in autocratic Russia. Almost fifty years ago Michael Cherniavsky described this political theology in his book Tsar and People, basing his 
comparative historical framework in part on Ernst Kantorowicz's classic work The King's Two Bodies: A Study in Mediaeval Political Theology. "The myth of the pious ruler drew its strength from the eschatology of Russian political theory," Cherniavsky wrote. "From its beginning around 1500, the Third Rome, Moscow, was the chief fact in the economy of salvation. Upon the orthodoxy and personal piety of the tsar depended the salvation of Russia as a state and thereby the salvation of the whole world." ${ }^{40}$ Beginning with Peter the Great, the ideology of Russian autocracy was partly Westernized and secularized, but after the assassination of Alexander II in 1881 there was a return to a religious image of monarchy. Richard Wortman has shown that Alexander III and Nicholas II both projected "scenarios of power," showing themselves as pious Muscovite rulers who believed themselves responsible for their people's salvation. ${ }^{41}$

Against the old political theology of autocracy, Problems of Idealism advanced a new political theology of personhood (cf. Metz's "political theology of the subject"). Following Kant, Russian neo-idealists defined the essence of personhood as the human capacity for morality or for selfdetermination-which capacity was the anthropological basis, in turn, for freedom of conscience as a natural right. Recognition of the absolute value of personhood and of its natural rights was incompatible in principle with autocracy, and stipulated, for nearly all the volume's contributors, the constitutional limitation of political power and the rule of law. At the beginning of Russia's long age of revolution, the new political theology of personhood thus took the practical form of liberalism. This was a type of liberalism that, in contrast to prevailing positivist conceptions (e.g., in Pavel Miliukov), was self-consciously idealist and, for most of its proponents, ultimately theological. While the old Russian political theology made religion an instrument of state power, the new political theology made it a limit of such power.

VII

The clearest formulations of the new Russian political theology of personhood can be found in what are surely the two best essays in Problems of Idealism: Bulgakov's "Basic Problems of the Theory of Progress" 
and Novgorodtsev's "Nravstvennyi idealizm v filosofii prava" ("Ethical Idealism in the Philosophy of Law"). ${ }^{42}$ Bulgakov's essay, which opens the volume, is one of his finest. He begins with a straightforward refutation of positivism: the idea or category of the absolute (whether in the form of morality, religion, or metaphysics) cannot be derived from the positive data of sense experience (the positivist criterion of reality), and yet it is intrinsic to human consciousness and cannot be eradicated. ${ }^{43}$ Positivist attempts to deny the presence of the absolute lead only to unconscious metaphysics, since it then enters into thought as "contraband"-it is smuggled in under the guise of scientific, historical, social or other concepts, rather than being openly recognized and justified before reason $(96,107)$. The result is that the relative and absolute are distorted and conflated with each other.

Bulgakov's brilliant case study of this type of conflation is the positivist theory of progress (under which he includes both Comte's and Marx's version). "For humanity today," he writes, "the significance of the theory of progress is that it is called upon to replace lost metaphysics and religion, or, more precisely, it takes the form of both" (91). In Bulgakov's analysis, the theory of progress turns out to be a pseudo-scientific, secular "religion of progress" because it posits a perfect human futurea future like nothing that could be positively extrapolated from the human past, but rather one that has overcome worldly contingency as such and achieved absolute perfection (97). Here the theory of progress betrays its debt to traditional religious faith in salvation, which obviously is not "positively given" but reflects human longing for the absolute. At the same time, "it wants to inspire confidence in the certain advent of this future kingdom through science," with its alleged ability to identify the laws of history and predict their necessary course (92-93). Thus the theory of progress not only promises a perfect (though utterly unverifiable) future, but also promises that it will come about "externally" through historical necessity, not through human self-determination and striving toward a transcendent, absolute ideal.

Bulgakov holds that ultimately the theory of progress fails because positivism cannot contend with the problem of personhood, which must rest on idealist and theistic foundations. The very concept of the 
person contradicts positivism's premises: it is a moral and metaphysical concept derived from the will's self-determination by the law or ideal of "ought" - which is of "supra-empirical origin" (105-06). "Ought," as a moral demand directed toward the will, is an ideal of action; it can autonomously motivate us, despite the claims of historical determinism to the contrary.

With this Bulgakov turns directly to the theme that would still occupy him thirty years later in "The Soul of Socialism" - the philosophy of history, or, as he prefers to call it here, the metaphysics of history, defined as "the discovery of the absolute in the relative" (108). "And if the absolute is a synonym for freedom," he writes, "then the metaphysics of history is the revelation of the principle of freedom in history, its victory over mechanical causation" (109). The metaphysics of history is not some abstract, impersonal schema: the absolute is recognized by persons in conscience as the moral law or categorical imperative, and persons are responsible for progressively realizing the absolute in history.

The moral law, according to Bulgakov, commands us "to want progress. From this point of view, progress is not a law of historical development," as it is in positivism, "but a moral task." In this idealist conception of it, progress requires inner strength. By contrast, "the positivist theory of progress flatters our weakness; it ... promises the external support of the natural course of things to that which does not find adequate support internally. In this, the positivist theory of progress represents its own type of eschatology, invoked to inspire warriors and sustain religious faith in the final triumph of the good. But another type of eschatology is needed before man can find in it real support for his moral activity" (111). This second type of eschatology is the one that Bulgakov will later call "Christian humanist." It respects human autonomy and dignity and recognizes that salvation or the Kingdom of God can be achieved only through what Kant called the kingdom of ends, which Bulgakov mentions in this context (112). ${ }^{44}$ "This is the true theory of progress-is any other needed!" Remarkably, Bulgakov has shown that this theory of progress (idealist and theistic) is consistently humanist, while the purported humanism of positivism (materialist and atheistic) actually shares the external, misanthropic approach to salvation of the old political theology. 


\section{VIII}

Novgorodtsev, in his chapter of Problems of Idealism, is less explicitly theological than Bulgakov and more political. His topic is the revival of natural law, and he is more specifically interested than Bulgakov in developing neo-idealism as a theory of liberalism. Nonetheless, there is broad and impressive philosophical agreement between them. Their common themes are personhood, progress, the critique of positivism, and the philosophy of history. Both philosophers are centrally concerned with rescuing history from positivist determinism and restoring it as the sphere of human freedom.

For Novgorodtsev, the openness of history defines the very task and importance of natural law. According to him, natural law reveals a constant human need: "This is the need consciously to go forward to meet the future, as yet undetermined and still within our power, as it were, and to realize in it our ideal strivings and hopes" (283). In another formulation, he writes: "Human thought has this quality of living not only in the present, but also in the future, of bringing to the future its ideals and aspirations, and in this sense natural-law constructions are an integral property of our spirit and testimony to its higher calling" (284). Decades later, Bulgakov would write of the "sense of an orientation toward the future," and Metz, in terms even more strikingly similar than those of Novgorodtsev, of the Noch-nichtgewesene. Like them, Novgorodtsev relates the openness of history to the power of utopian ideals to shape the future (292).

The task of natural law, as he understands it, is to order ideal paths of progressive development. Natural law is about the future of law, and in this its guide is the moral ideal of "what ought to be" (286). The ideal nature of natural law (in contrast to positive law) makes it "a norm and principle of personhood" (303). This is an intricate connection: the moral ideals that take juridical form in natural law are the same ideals that make self-determination and therefore personhood itself possible. The idea of personhood was the center of Novgorodtsev's philosophical liberalism, from its treatment of ethics to its treatments of law and public policy. His ultimate social ideal was the "kingdom of ends." "The self-determining person," he writes, "is the ground on which is raised the supreme good of the moral world, 'the kingdom of persons as ends', in Kant's expression" 
(305). This "supreme good" is not only a moral one but also a broadly theological one; it fits squarely within the humanist tradition of the new political theology.

Novgorodtsev stressed the core liberal implication of his theory of natural law and of personhood: the inalienable rights of the person solidly mark the limits of state power. In the modern conception, he writes, "natural law is the expression of the autonomous, absolute significance of the person, a significance that must belong to it in any political system. In this respect natural law is more than a demand for better legislation: it represents the protest of the person against state absolutism, reminding us of the unconditional moral basis that is the only proper foundation of society and the state" (313). Novgorodtsev thought that the absolute value of the person held theistic implications-though in his Problems of Idealism essay he points only rather obliquely to a "higher metaphysical synthesis" (314) — so that his idealist liberal theory incorporates, indeed rests on, a political theology of personhood. In tsarist Russia, where in 1902 Konstantin Pobedonostsev had starkly symbolized the old political theology of autocracy for over twenty years, his ideas must have resonated.

\section{IX}

The great divide between Problems of Idealism and Vekhi was, of course, the 1905 revolution. The Vekhi authors blamed the radical intelligentsia and its positivist ideology for the failure of Russian liberalism in the aftermath of the revolution. Vekhis criticisms of the intelligentsia drew heavily on Problems of Idealism, in particular on its critique of positivism, its defense of neo-idealism, and its political theology of personhood. Five of the seven Vekhi authors had contributed to Problems of Idealism. The initiative for the earlier volume came from Struve, who was also an important inspiration behind Vekhi.

Struve's Vekhi essay, "Intelligentsiia i revoliutsiia" ("The Intelligentsia and Revolution"), highlights a central philosophical continuity between the two volumes, namely their religious-philosophical humanism. In 1905 Struve wrote an essay with Semen Frank on the philosophy of culture. In it they offer a defense of humanism, "by which we mean idealism, a faith in 
absolute values which is linked with faith in humanity and its creative tasks on earth." ${ }^{45}$ Pipes suggests that their philosophy of culture drew directly on Kant's idea of human self-determination. ${ }^{46}$ "Culture is creativity," they wrote, "the conscious and deliberate transformation of reality in accord with ideals." ${ }^{47}$ In Vekhi, Struve applies this same idealistic humanism to religion, writing that any true religion must rest on "faith in the redemptive power and decisive importance of personal creation, or, more truly, of personal achievement [podvig] in conformity with the will of God." ${ }^{48}$ Like Lev Tolstoi, whom he greatly admired, Struve believed that "the Kingdom of God is within you," and that "for the religious mind, therefore, nothing can be more important than a person's individual self-perfection" (120). The atheistic intelligentsia, in denying the existence of ideals (as its positivism stipulated), also denied itself the possibility of self-determination and selfperfection, of personal achievement and responsibility.

Despite his impressive formulation of important tenets of Russian religious humanism, Struve seems to reject the "political religions" approach to understanding the intelligentsia's psychology, as advanced by Solov'ev, Bulgakov, and others. His argument refuting this approach is that the alleged religiosity of the intelligentsia's outlook and ideologies was purely a matter of form, not content $(119,124)$-but this is precisely what proponents of the "political religions" approach claim. He also rejected the idea of "Christian politics." ${ }^{9}$

\section{$x$}

In his famous Vekhi essay, "Heroism and Asceticism: Reflections on the Religious Nature of the Russian Intelligentsia," Bulgakov applies his 1902 critique of the theory of progress more specifically to the Russian intelligentsia. The essay is a classic analysis of the intelligentsia's political religions. According to Bulgakov, an eschatological "striving for the salvation of mankind" was the intelligentsia's distinctive trait (21). In this external sense of the concept, eschatology captures the "heroism" that was central to the intelligentsia's "entire spiritual economy" (27). "The very essence of heroism," he writes, "presupposes a passive object of activity, the nation or humanity that is being saved" (29). The intelligentsia's heroic 
mission was the "external salvation of mankind"; it rested on "an arrogant view of the people as an object of salvation" $(39,43)$. The intelligentsia's salvific heroism can be traced, Bulgakov argues, to the circumstances under which the radical intelligentsia emerged-to persecution, suffering, and a type of martyrdom under the tsarist police regime. He leaves unstated an interesting paradox: the Russian autocracy's political theology thus gave rise to the intelligentsia's political religions, both premised on the idea that they were responsible for the people's salvation.

The external means by which the intelligentsia hoped to bring about the salvation of Russia and humanity was the positivist theory of progress that Bulgakov analyzed in Problems of Idealism. The intelligentsia took the atheism of this theory as an article of faith. In Vekhi, Bulgakov is highly critical of "humanism," here associating the term (despite the real humanism of his own religious philosophy) with atheism and with the intelligentsia's faith in humanity's natural goodness, corrupted only by irrational or defective external circumstances (such as religion). In the "humanistic intelligentsia church" (22), salvation is understood as something that will take place automatically through rational, necessary historical development toward socialism. With this belief, "the intelligentsia lives in an atmosphere of expectation, awaiting the social miracle, the universal cataclysm-it lives in an eschatological frame of mind" (30).

Bulgakov draws a crucial implication from this "heroic" type of eschatology: it cannot provide a real basis for personhood because (to put it somewhat more philosophically than he does) it cannot sustain an ideal, which is a necessary condition for self-determination and self-development. Self-determination (which capacity defines personhood) requires an ideal by which the will can be self-determining. "Heroic" eschatology collapses the ideal to an immanent process of automatic historical development. Salvation happens through historical necessity, not through the selfdetermination of persons acting in history according to higher, ultimately transcendent ideals. These considerations explain why "the absence of a correct doctrine of personhood is the intelligentsia's chief weakness" (34).

Bulgakov commends not heroism but asceticism (podvizhnichestvo) or humility, which he considers to be self-discipline, self-mastery, and self-perfection-in short, as the religious cultivation of personhood. In 
its recognition of "absolute norms and values," asceticism can serve "as an inner structuring of personhood" $(36,38)$. It is oriented not toward external salvation, the salvation of others, but toward inner salvation, the salvation of oneself. In opposition to Enlightenment notions of the natural goodness and (mechanical) perfection of human nature, asceticism requires recognition of sin and a willingness to struggle against it, first of all within oneself. Despite the inward emphasis of asceticism, Bulgakov argues that the same ideals that make self-determination (and personhood) possible are also culturally and economically creative. Ascetic obedience to one's duty can be applied to any field of "external" activity: the discipline of obedience or "worldly asceticism" cultivates the self through work in the world (39). Though some of Bulgakov's language sounds archaic and though he opposes the term "humanism," his overall case for asceticism directly anticipates his later "Christian humanism." Asceticism is already the new political theology, while heroism is the old.

\section{XI}

In his Vekhi essay, "Etika nigilizma: k kharakteristike nravstvennogo mirovozzreniia russkoi intelligentsii” ("The Ethic of Nihilism: A Characterization of the Russian Intelligentsia’s Moral Outlook”), Frank does use the term "humanism" to describe his philosophical worldview, one which bears striking similarities not only to Struve's but also to Bulgakov's. All three thinkers were concerned perhaps above all with the role of objective ideals and of absolute values in the constitution of personhood and in cultural creativity. The concepts of "heroism" and "nihilism" are different ways of describing the loss of the ideal and the consequences of that loss. Bulgakov emphasizes the consequences for personhood, while Frank emphasizes those for culture. Frank defines nihilism as "the denial or non-recognition of absolute (objective) values" (136). The inevitable result is the creation of false absolutes or idols, the ascribing of absolute significance to one or another relative value or interest (fanaticism). A good example, according to Frank, is the intelligentsia's "moralism," by which everything is judged according to the utilitarian criterion (and false absolute) of the people's happiness. The intelligentsia's faith in the inevitability of universal human 
happiness drove its "theory of progress," its "religion of socialism," and its belief that it held the key to "the universal salvation of mankind" (142-43). On this point Frank's analysis is very similar to Bulgakov's.

In Vekhi Frank devotes relatively more attention than Bulgakov to outlining an idealist theory of culture. Clearly drawing on his 1905 essay written with Struve, he defines culture as "the aggregate of objective values which have been actualized by the historical development of social life" (139, italics removed). In this conception, culture is the ever-richer embodiment and ever-greater realization of ideals and values in life through human selfdetermination and aspiration. This is the real dynamic of progress. It also underlies what Frank calls the "metaphysical concept of wealth" and the intelligentsia's aversion to it: "The Russian intelligentsia does not love wealth. In the first place, it does not value spiritual wealth, or culture-the ideal force and creative activity of the human spirit that impels it to master and humanize the world and to enrich its life with the values of science, art, religion and ethics. What is more remarkable, it even extends this dislike to material wealth, instinctively recognizing its symbolic connection with the general idea of culture" (148). It is clear that the nihilist (and more broadly positivist) denial of the ideal-without which there is no object for the will's self-determination and nothing to be embodied in life-cannot but impoverish personhood, culture, and economy. By contrast, recognition of the ideal-which ultimately meant metaphysical theism for Bulgakov, Frank, Novgorodtsev, and Struve-enriches them. This is why Frank concludes his article (and Vekhi) with the following call: "We must pass from unproductive, anti-cultural nihilistic moralism to creative, culturally constructive religious humanism" (155).

\section{XII}

Within ten years and in the midst of another Russian revolution, $I z$ glubiny (Out of the Depths, 1918) appeared as a type of sequel to Problems of Idealism and Vekhi. ${ }^{50}$ Some of its essays also pursue the critique of the old political theology, whether in the form of the old regime's appropriation of religion for its own ideological purposes or in the form of the intelligentsia's political religions. By 1918, however, the Great War had radically 
undermined the premises of liberal theology all over Europe. In 1919 Karl Barth published his Der Römerbrief (Epistle to the Romans), one of the most important theological works of the twentieth century. "The book's adversary was every form of liberal theological humanism," in Mark Lilla's recent estimation..$^{51}$ The point of all its rich metaphors and images "is to show that there can never be a fusion of the human and divine, either in morality or in history," Lilla writes. "The God of Romans could not be further from ... Kant's moral lawgiver." ${ }^{52}$ Barth and other Weimar-era theologians cast Kant aside and returned to Augustine, with his emphasis on original sin-the depravity of human nature-and our need for total redemption. Their new theology was the old one of the need for salvation from ourselves.

The theological currents of Weimar Germany may seem worlds apart from the Marxism-Leninism of the Soviet Union during this era. In fact, they shared certain presuppositions about human nature. Lenin created Leninism when he pronounced the proletariat incapable of developing its own true class consciousness-which was the precondition of communism. As a result, such consciousness would have to be brought to the proletariat from without, by a vanguard party of professional revolutionaries. In other words, the workers had to be saved from themselves, and the external agent of salvation was the party. Lenin's contempt for humanity had much in common with Carl Schmitt's. It is for good reason that one recent scholar writes that Schmitt's thought suggests "a kind of right-wing Leninism." 53

Europe's theological despair, in its various forms, began to lift with the post-1945 appearance of the new political theology, representing as it does a revival of earlier traditions of liberal theological humanism. Its further development has much to gain from the rich resources of Russia's tradition of religious-philosophical humanism. 
1 See two recent large anthologies: Peter Scott and William T. Cavanaugh, eds., The Blackwell Companion to Political Theology (Malden, MA: Blackwell, 2004); and Hent de Vries and Lawrence E. Sullivan, eds., Political Theologies: Public Religions in a PostSecular World (New York: Fordham University Press, 2006).

2 Bernd Wacker and Jürgen Manemann, "Political Theology: History of a Concept," in Missing God? Cultural Amnesia and Political Theology, ed. John K. Downey, Jürgen Manemann, and Steven T. Ostovich (Berlin: LIT Verlag, 2006), 170-81.

3 Johann Baptist Metz, Faith in History and Society: Toward a Practical Fundamental Theology, ed. and trans. J. Matthew Ashley (New York: Crossroad, 2007).

4 Ibid., 70-84.

5 Rowan Williams, ed. and intro., Sergii Bulgakov: Towards a Russian Political Theology (Edinburgh: T\&T Clark, 1999). Further references to this edition are given in parentheses in the text.

6 He does not refer to Metz, but suggests that Bulgakov's political theology might be compared to the ideas of John Milbank, Stanley Hauerwas, and William Stringfellow (Ibid., 233-34).

7 Sergei Bulgakov, Philosophy of Economy: The World as Household, ed. and trans. Catherine Evtuhov (New Haven, CT: Yale University Press, 2000).

8 This definition recalls Rudolf Stammler's formula for natural law. On Bulgakov and Stammler, see Catherine Evtuhov, The Cross and the Sickle: Sergei Bulgakov and the Fate of Russian Religious Philosophy, 1890-1920 (Ithaca, NY: Cornell University Press, 1997), 30, 40.

9 Sergej N. Bulgakov, Sozialismus in Christentum?, ed. and trans. Hans Jürgen Ruppert (Göttingen: Vandenhoeck und Ruprecht, 1977).

10 J. B. Metz, Glaube in Geschichte und Gesellschaft: Studien zu einer praktischen Fundamentaltheologie (Mainz: Matthias-Grünewald Verlag, 1977). Parenthetical page references are to the English edition cited in note 3 above.

11 For a fine, succinct presentation of Metz's thought, with due attention to the Kantian and Marxian influences, see J. Matthew Ashley, "Johann Baptist Metz," in Scott and Cavanaugh, Blackwell Companion to Political Theology, 241-55.

12 J. B. Metz, Christliche Anthropozentrik: Über die Denkform des Thomas von Aquin (Munich: Kösel-Verlag, 1962).

13 Eighty years earlier Vladimir Solov'ev, Russia’s greatest religious philosopher, wrote, "In man's consciousness and his freedom is the inner possibility for each human being to stand in an independent relation to God." Vladimir Solovyov, The Justification of the Good: An Essay on Moral Philosophy, trans. Nathalie A. Duddington, ed. and annotated Boris Jakim (Grand Rapids, MI: William B. Eerdmans Publishing Company, 2005), 149-50.

14 J. B. Metz, Zur Theologie der Welt (Mainz: Matthias-Grünewald, 1968); Theology of the World, trans. William Glen-Doepel (New York: Herder, 1969). The title echoes 
that of Lev Zander's massive study of Bulgakov' God and World: L. A. Zander, Bog i mir (Mirosozertsanie ottsa Sergiia Bulgakova), 2 vols. (Paris: YMCA Press, 1948). In this connection see Paul Valliere, "A Russian Cosmodicy: Sergei Bulgakov's Religious Philosophy," in A History of Russian Philosophy, 1830-1930: Faith, Reason, and the Defense of Human Dignity, ed. G. M. Hamburg and Randall A. Poole (Cambridge: Cambridge University Press, 2010), 171-89.

15 As quoted by J. Matthew Ashley in his introduction to Metz, Faith in History and Society, 15.

16 Ibid.

17 Steven T. Ostovich, "Melancholy History," in Downey, Manemann, and Ostovich, Missing God?, 93-101.

18 S. N. Bulgakov, "Basic Problems of the Theory of Progress," in Problems of Idealism: Essays in Russian Social Philosophy, trans. and ed. Randall A. Poole (New Haven, CT: Yale University Press, 2003), 85-123.

19 S. N. Bulgakov, “Ivan Karamazov kak filosofskii tip," Voprosy filosofii i psikhologii 13: 1, kn. 61 (1902): 826-63; reprinted in his collection Ot marksizma k idealizmu. Sbornik statei (1896-1903) (St. Petersburg: Tovarishchestvo "Obshchestvennaia literatura", 1903), 83-112.

20 Bulgakov, "Basic Problems of the Theory of Progress," 103; Metz, Faith in History and Society, 123.

21 See Metz, Faith in History and Society, ch. 6, "The Future Seen from the Memory of Suffering: On the Dialectic of Progress," 97-113. I do not know if Metz had any familiarity with Bulgakov. He need not have in order to have arrived at a similar theology: they both drew on a common philosophical and theological discourse that awaited fuller development into powerful humanist theologies. That both thinkers pursued this direction attests to their caliber as theologians, not necessarily to Bulgakov's influence on Metz.

22 Wacker and Manemann, "Political Theology: History of a Concept," 177.

23 Ibid., 174.

24 Carl Schmitt, Political Theology: Four Chapters on the Concept of Sovereignty, trans. George Schwab, foreword Tracy B. Strong (Chicago: University of Chicago Press, 2005), 2.

25 Carl Schmitt, The Concept of the Political, trans. George Schwab (Chicago: University of Chicago Press, 1996), 26.

26 For three excellent accounts of Schmitt's illiberalism and its dangers, see Michael Hollerich, "Carl Schmitt," in Scott and Cavanaugh, Blackwell Companion to Political Theology, 107-22; Mark Lilla, The Reckless Mind: Intellectuals in Politics (New York: New York Review Books, 2001), 47-76; and Steven Ostovich, "Carl Schmitt, Political Theology, and Eschatology," KronoScope 7 (2007): 49-66.

27 Among their many relevant works, see W. Gurian, Bolshevism: An Introduction to Soviet Communism (Notre Dame: University of Notre Dame Press, 1953), the first chapter of which is "Bolshevism as Social and Political Religion"; K. Löwith, Meaning in 
History (Chicago: University of Chicago Press, 1949); and E. Voegelin, Die politischen Religionen (Vienna: Bermann-Fischer, 1938).

28 See Andrzej Walicki, "Russian Philosophers of the Silver Age as Critics of Marxism," in Russian Thought after Communism: The Recovery of a Philosophical Heritage, ed. James P. Scanlan (Armonk, NY: M. E. Sharpe, 1994), 81-103.

29 V. S. Solovyov, Lectures on Divine Humanity, trans. Boris Jakim (Hudson, NY: Lindisfarne Press, 1995), 2.

30 All three are available in English: the first in Problems of Idealism (see note 18 above); the second as Karl Marx as a Religious Type: His Relation to the Religion of Anthropotheism of L. Feuerbach, trans. Luba Barna, ed. Virgil R. Lang, and intro. Donald W. Treadgold (Belmont, MA: Nordland, 1979); and the third in Vekhi/Landmarks: A Collection of Articles about the Russian Intelligentsia, trans. and ed. Marshall S. Shatz and Judith E. Zimmerman (Armonk, NY: M. E. Sharpe, 1994), 17-49, as well as in the Williams collection.

31 P. I. Novgorodtsev, Ob obshchestvennom ideale, ed. A. V. Sobolev (Moscow: Pressa, 1991). This work was first serialized in Voprosy filosofii i psikhologii, 1911-16, and then published in three editions (Moscow, 1917; Kiev, 1918; and Berlin, 1921). For analysis see Andrzej Walicki, Legal Philosophies of Russian Liberalism (Oxford: Clarendon Press, 1987), 328-41.

32 An English translation of his 1906 essay "Socialism as Religion" can be found in Bernice Glatzer Rosenthal and Martha Bohachevsky-Chomiak, eds., A Revolution of the Spirit: Crisis of Value in Russia, 1890-1924 (New York: Fordham University Press, 1990), 107-33.

33 Nicolas Berdyaev, The Origin of Russian Communism, trans. R. M. French (Ann Arbor: University of Michigan Press, 1960), 143-44.

34 For example, Stephen Kotkin, Magnetic Mountain: Stalinism as a Civilization (Berkeley: University of California Press, 1995), esp. chapter 7. Kotkin calls his own comparison of the Stalinist party-state to a theocracy a "revisionist characterization." See also Igal Halfin, From Darkness to Light: Class, Consciousness, and Salvation in Revolutionary Russia (Pittsburgh: University of Pittsburgh Press, 2000). For a recent powerful interpretation of Nazism as a political religion, see Michael Burleigh, The Third Reich: A New History (New York: Hill and Wang, 2000).

35 Richard F. Gustafson, "Soloviev's Doctrine of Salvation," in Russian Religious Thought, ed. Judith Deutsch Kornblatt and Richard F. Gustafson (Madison: University of Wisconsin Press, 1996), 31-48; and Randall A. Poole, "Solov'ëv's Philosophical Anthropology: Autonomy, Dignity, Perfectibility," in Hamburg and Poole, History of Russian Philosophy, 131-49.

36 The humanism of modern Russian theology has been treated most recently and systematically by Paul Valliere, Modern Russian Theology: Bukharev, Soloviev, Bulgakov: Orthodox Theology in a New Key (Grand Rapids, MI: William B. Eerdmans Publishing Company, 2000).

37 See Greg Gaut, "Christian Politics: Vladimir Solovyov's Social Gospel Theology," Modern Greek Studies Yearbook 10/11 (1994-95): 653-74; and Gaut, "Can a Christian 
Be a Nationalist? Vladimir Solov'ev's Critique of Nationalism,' Slavic Review 57, no. 1 (Spring 1998): 77-94.

38 For the project's conception and history, see my introduction to Problems of Idealism.

39 See my essay "Religious Toleration, Freedom of Conscience, and Russian Liberalism," Kritika: Explorations in Russian and Eurasian History 13, no. 3 (Summer 2012): 611-34.

40 Michael Cherniavsky, Tsar and People: A Historical Study of Russian National and Social Myths (New Haven, CT: Yale University Press, 1961), 71. Isabel de Madariaga agrees. In her recent study Ivan the Terrible (New Haven, CT: Yale University Press, 2005), she writes that "fundamental to Ivan's conception of his role as Tsar was his responsibility for the eternal salvation of his people" (378).

41 Richard S. Wortman, Scenarios of Power: Myth and Ceremony in Russian Monarchy, vol. 2 (Princeton: Princeton University Press, 2000), ch. 7.

42 Berdiaev's essay "Eticheskaia problema v svete filosofskogo idealizma" ("The Ethical Problem in the Light of Philosophical Idealism") is also directly relevant, but beyond the scope of this article.

43 Poole, Problems of Idealism, 85-89. Subsequent parenthetical pages references are to this edition.

44 In Justification of the Good, Solov'ev explicitly argues that the Kingdom of God can be achieved only through the kingdom of ends (149-50). Bulgakov could hardly have had higher regard for Solov'ev, writing that his "philosophy is so far the last word in world philosophical thought, its highest synthesis" (116).

45 P. B. Struve and S. L. Frank, “Ocherki filosofii kul'tury," pt. 1, “Chto takoe kul'tura?," Poliarnaia zvezda no. 2 (1905): 115. As quoted and cited in Aileen M. Kelly, "Which Signposts?" in her Toward Another Shore: Russian Thinkers between Necessity and Chance (New Haven, CT: Yale University Press, 1998), 175. In this essay Kelly contrasts the humanism of Struve and Frank to what she understands as the illiberal religious and national messianism of Berdiaev and Bulgakov. I think Bulgakov's position is more complicated.

46 Richard Pipes, Struve: Liberal on the Right, 1905-1944 (Cambridge, MA: Harvard University Press, 1980), 85-86.

47 P. B. Struve and S. L. Frank, "Ocherki filosofii kul'tury," pt. 2, "Kul'tura i lichnost," Poliarnaia zvezda no. 3 (1905): 174-75. As quoted and cited in Pipes, 86.

48 Shatz and Zimmerman, Vekhi/Landmarks, 119. Subsequent parenthetical page references to Vekhi are to this edition.

49 Pipes, Struve, 99.

50 Out of the Depths (De Profundis): A Collection of Articles on the Russian Revolution, trans. and ed. William F. Woehrlin (Irvine, CA: Charles Schlacks, 1986).

51 Mark Lilla, The Stillborn God: Religion, Politics, and the Modern West (New York: Alfred A. Knopf, 2007), 261.

52 Ibid., 263.

53 Tracy B. Strong, "Foreword" to Schmitt, Political Theology, xxviii. 